\title{
Coexistence of Allergic Rhinitis in Children Attending Paediatric Asthma Clinic
}

\section{Rajesh Kumar Singh ${ }^{1}$ and Ashish Kumar Simalti ${ }^{2}$}

${ }^{1}$ Department of Paediatrics, Command Hospital (Eastern Command) Kolkata, India

${ }^{2}$ Department of Paediatrics, Army Hospital Research and Referral, New Delhi, India

\section{Correspondence: \\ Ashish Kumar Simalti \\ Department of Paediatrics \\ Army Hospital Research and Referral, \\ New Delhi, India \\ Email: ashishsimalti@rediffmail.com}

DOI:10.3126/jnps.v39i3.26494

Submitted on: 2019-11-29

Accepted on: 2020-05-03

Acknowledgements: None.

Funding: Nil

Conflict of Interest: None declared

Permission from IRB: Yes
To cite this article: Singh K, Simalti AK. Coexistence of allergic rhinitis in children attending paediatric asthma clinic. J Nepal Paediatr Soc. 2019;39(3):142-6.

\section{ABSTRACT}

Introduction: Asthma and allergic rhinitis are considered manifestations of the chronic inflammatory respiratory syndrome of the common airways or united airways disease. We conducted a prospective epidemiological study to evaluate the prevalence of allergic rhinitis among children already diagnosed as having asthma.

Methods: A prospective epidemiological study was carried out during 2015 to 2016 at a tertiary care centre in North India. The severity of asthma was classified according to the Global Initiative for Asthma (GINA) report \& allergic rhinitis according to Allergic Rhinitis and Its Impact on Asthma (ARIA).

Results: A total of 64 children were screened. After excluding five subjects (7.8\%), 59 subjects with asthma were analysed. We could not find any definitive correlation between severity of asthma to severity of allergic rhinitis $(p>0.05)$. The prevalence of co morbidity of asthma and allergic rhinitis was maximum when onset of asthma was between three to six years (70\%), was $40 \%$ for $<$ three years and $50 \%$ when age of onset was six to nine years. The age of onset of asthma in children having asthma only was five years and that of children with both asthma and allergic rhinitis was 5.5 years. This difference was not significant $(\mathrm{p}>$ $0.05)$.

Conclusion: There was a high prevalence of co morbidity (50.84\%) of allergic rhinitis among patients with asthma. A positive correlation was found between duration and severity of asthma, but this was not observed for allergic rhinitis. In most cases asthma preceded or started with AR.

Key words: allergic asthma; allergic rhinitis; comorbidity 


\section{INTRODUCTION}

Asthma and allergic rhinitis are now considered as manifestations of the chronic inflammatory respiratory syndrome of the common airways, or united airways disease. ${ }^{1-3}$ The link between asthma and allergic rhinitis has been established in clinical observations and epidemiological studies and also on the basis of immunological observations and outcomes of therapy. ${ }^{4-6}$ World Health Organisation (WHO) and the ARIA Initiative (Allergic Rhinitis and Its Impact on Asthma) released a comprehensive overview of the pathophysiology, diagnosis and therapy of allergic rhinitis. ${ }^{2}$ About $4 \%$ to $11 \%$ of the general population has asthma, whereas the prevalence of allergic rhinitis is around $10 \%$ to $30 \%$. ${ }^{7,8}$ Between $20 \%$ and $50 \%$ of patients with allergic rhinitis have asthma and $30 \%$ to $90 \%$ of patients with asthma have concomitant rhinitis. ${ }^{9-11}$ Prevalence of bronchial asthma among children in India is increasing at a faster rate than previously understood. ${ }^{12}$ The prevalence of asthma was estimated to be $17.14 \%$ and allergic rhinitis was $21.29 \%$ in an Indian study. ${ }^{13}$ Uncertainty exists, however, as to whether the severity of allergic rhinitis is related to the severity of asthma. This study was conducted to evaluate the prevalence of allergic rhinitis among children already diagnosed as having asthma in patients attending paediatric asthma outpatient clinic. Secondary objective was to correlate onset of allergic rhinitis with duration and severity of asthma.

\section{METHODS}

A prospective epidemiological study was carried out during 2015 to 2016 at a tertiary care centre in North India. The children attending Paediatric asthma clinic were recruited in the present study. After obtaining written informed consent, the participating physicians administered a structured questionnaire based on ARIA guidelines. Two or more symptoms like sneezing, watery rhinorrhea, nasal itching and nasal obstruction persisting beyond one hour on many days were considered as suggestive of AR while symptoms like stuffiness only involving one nostril, mucoid postnasal drip, mucopurulent rhinorrhea, recurrent epistaxis, pain and anosmia were considered as not related to AR. Clinical diagnosis was confirmed by the serumspecific IgE levels. Besides demographic data, we had also included few questions related to risk factors which were easy for patients to answer namely exposure to pets or other animals, smoking by care givers, personal and family history of atopy. Since looking for risk factors of AR was not one of the objectives of this particular study we did not include skin prick test to common allergens. The severity of asthma was classified according to the Global Initiative for Asthma (GINA) report ${ }^{14,15}$ and allergic rhinitis according to ARIA., ${ }^{2,16}$ Ethical clearance was taken from Hospital Ethical Committee. Statistical tests were performed using chi square test, unpaired $t$ test..

\section{RESULTS}

A total of 64 children of age group one to 15 years were screened. After excluding five children (7.8\%) due to incomplete data collection, 59 subjects with asthma were analysed. Clinical and demographic data of the study population are shown in Table 1 . Classification of asthma severity in these patients was done according to GINA, at onset of asthma before control could be achieved. Subjects with more severe asthma tended to be older than those

Table 1. Demographic and clinical characteristics of the study population $(\mathrm{N}=59)$

\begin{tabular}{|c|c|c|}
\hline Variables & & Percentage \\
\hline \multirow[t]{2}{*}{ Gender } & Female & $26 \%$ \\
\hline & Male & $74 \%$ \\
\hline \multirow[t]{5}{*}{ Age wise distribution } & Below 1 year & $30.50 \%$ \\
\hline & $1-3$ years & $17 \%$ \\
\hline & $3-5$ years & $25.4 \%$ \\
\hline & $5-10$ years & $22 \%$ \\
\hline & $\begin{array}{l}\text { More than } 10 \\
\text { years }\end{array}$ & $5 \%$ \\
\hline \multirow{2}{*}{$\begin{array}{l}\text { Exposure to domestic } \\
\text { animals in household }\end{array}$} & Yes & $32 \%$ \\
\hline & No & $68 \%$ \\
\hline \multirow[t]{3}{*}{ Family history } & $\begin{array}{l}\text { Allergic } \\
\text { Rhinitis }\end{array}$ & $30 \%$ \\
\hline & Asthma & $59 \%$ \\
\hline & Both & $20 \%$ \\
\hline \multirow[t]{3}{*}{$\begin{array}{l}\text { Personal history of } \\
\text { allergic diseases }\end{array}$} & $\begin{array}{l}\text { Atopic } \\
\text { dermatitis }\end{array}$ & $6 \%$ \\
\hline & Food allergy & Nil \\
\hline & Urticaria & $11.8 \%$ \\
\hline
\end{tabular}


Table 2. Correlation of asthma and allergic rhinitis

\begin{tabular}{|c|c|c|c|c|c|c|c|}
\hline \multirow[t]{2}{*}{ SN } & \multirow[t]{2}{*}{ Asthma classification } & \multicolumn{5}{|c|}{ Allergic rhinitis classification } & \multirow{2}{*}{$\begin{array}{c}\text { Total } \\
\text { with AR }\end{array}$} \\
\hline & & No AR & $\begin{array}{l}\text { Mild } \\
\text { Intermittent }\end{array}$ & $\begin{array}{l}\text { Mild } \\
\text { Persistent }\end{array}$ & $\begin{array}{l}\text { Severe } \\
\text { Intermittent }\end{array}$ & $\begin{array}{l}\text { Severe } \\
\text { Persistent }\end{array}$ & \\
\hline 1 & Mild Intermittent & 2 & 4 & 2 & ? & 0 & 6 \\
\hline 2 & Mild Persistent & 22 & 9 & ( & 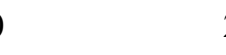 & 3 & 14 \\
\hline 3 & Moderate Persistent & 4 & 4 & ( & 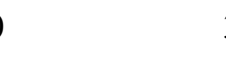 & 2 & 9 \\
\hline 4 & Severe Persistent & 1 & 0 & ( & 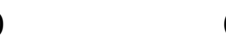 & 1 & 1 \\
\hline
\end{tabular}

with intermittent asthma. This was significant in patients with moderate persistent asthma $(\mathrm{P}<$ $0.001)$ and severe persistent asthma $(\mathrm{P}<0.001)$. Mean age of onset of asthma symptoms was 3.9 years. Mean age of onset of allergic rhinitis was 5.5 years. This difference was statistically significant. Seventy two percent of the children had asthma onset before age of five years. Concomitant allergic rhinitis affected $50.84 \%$ of patients with asthma.

Correlation of asthma with allergic rhinitis has been tabulated in table 2. According to the frequency of symptoms, allergic rhinitis was classified as intermittent in $73.3 \%$ and persistent in $26.6 \%$ of patients. Severity was stratified as mild in $63.3 \%$ and moderate-persistent in $36.6 \%$. The mean age of onset of allergic rhinitis was 5.5 years. The mean age of onset of intermittent rhinitis was 6.46 years and that for persistent rhinitis was 4.35 years. We could not find any definitive correlation between severity of asthma and severity of allergic rhinitis $(p>0.05)$, The prevalence of co-morbidity of asthma and allergic rhinitis was maximum when onset of asthma was between three to six years (70\%), was $40 \%$ for $<$ three years and $50 \%$ when age of onset was six to nine years. The age of onset of asthma in children having asthma only was five years and that of children with both asthma and allergic rhinitis was 5.5 years. This difference was not significant $(\mathrm{p}>0.005)$. Thirty two percent of asthma patients had animal exposure in early life, however it had no effect on age of onset of either asthma or AR.

A family history of rhinitis was a significant risk factor (OR 11.9; 95\% CI, 6.9 - 20.3) for comorbidity of allergic rhinitis and asthma. No significant differences were found between rural and urban habitat for the association between allergic rhinitis and asthma and no association was found for exposure to care giver's smoking habit.

\section{DISCUSSION}

Our study was conducted in children who were already diagnosed cases of asthma and were attending asthma clinic. As per our study for severity for asthma, $15 \%$ children had mild intermittent, $59 \%$ had mild persistent, $22 \%$ had moderate persistent and $3.4 \%$ children had severe persistent asthma. Prevalence of allergic rhinitis among patients with asthma was $50.84 \%$. Younger children have comparatively milder asthma while older patients had comparatively more severe asthma. It was observed that allergic rhinitis followed asthma in most of patients in our study. Most epidemiological studies on the interrelationship between allergic rhinitis and asthma have evaluated the prevalence of asthma among subjects suffering from allergic rhinitis, with frequencies ranging from $20 \%$ to $50 \%{ }^{17-21}$ or as high as $70 \%$ in a study conducted in young army recruits. ${ }^{22}$ The prevalence of allergic rhinitis among subjects with asthma in previous studies vary widely. Recent studies carried out in large population sample report prevalence between $80 \%$ and $95 \%$ of patients. ${ }^{6}$ In a study carried out in 3916 adults, $82 \%$ of subjects with asthma had allergic rhinitis. $^{23}$ Some studies point out that the prevalence of allergic rhinitis in adult patients with asthma is as high as $99 \%$ and in young people it can reach $95 \%{ }^{24-26}$

Researchers have studied the relationship of atopic dermatitis in early infancy with future development of AR and asthma known as 'atopic march'. ${ }^{27}$ Possible explanation of this phenomena is that a dysfunctional skin barrier of atopic dermatitis gets colonised with bacterial super antigens and leads to allergic sensitisation to antigens in early 
childhood. We found that the onset of asthma was earlier than the onset of allergic rhinitis and this difference was significant. This finding may indicate that we should regularly try to look for appearance of $\mathrm{AR}$ in patients presenting with asthma. In a study carried out in 738 students, Greisner et al. ${ }^{28}$ reported that $45 \%$ of subjects with both seasonal rhinitis and asthma developed rhinitis earlier, 35\% developed asthma before rhinitis, and $21 \%$ experienced both conditions simultaneously. In subjects with perennial rhinitis and asthma, 38\% developed rhinitis first, 31\% developed asthma before rhinitis, and $31 \%$ developed both conditions at the same time. Thus, in $70 \%$ to $80 \%$ of cases, allergic rhinitis begins before or at the same time as asthma. These data further emphasise the link between allergic rhinitis and asthma as manifestations of a common inflammatory airway disorder that often occur together during the natural history of the disease. In our study we could not establish any correlation between severity of asthma and allergic rhinitis. A Study by Navarro A et al. in adult patients noted that the severity of asthma and rhinitis has inverse correlation. ${ }^{29}$ In our study $58 \%$ of patients had mild intermittent AR, $6.5 \%$ had mild persistent, $16.1 \%$ had severe intermittent and $14.6 \%$ had severe persistent asthma. In adults Navarro et al calculated this to be mild intermittent (24\%), moderate/severe intermittent (22\%), mild persistent $(19 \%)$ and moderate / severe persistent (35\%). ${ }^{29}$ The prevalence of co existence of AR with asthma patients was maximum i.e. $70 \%$ when onset of asthma was between three to six years. No other study considered this aspect. We could not find any significance between urban versus rural and smoking habit for co-existence of asthma and AR. This study has limitation of the sample size to comment on risk factors for AR. This being a questionnaire based study may be subject to recall bias and subjectivity of study population. As the questionnaire was not weighted we cannot consider family history, exposure to smoke and pets as significant risk factors but these findings can be used to plan a larger study involving univariate and multivariate analysis of these risk factors.

\section{CONCLUSIONS}

In conclusion, our study reveals a high prevalence of co morbidity (50.84\%) of allergic rhinitis among patients with asthma. A positive correlation was found between duration and severity of asthma, but this was not observed for allergic rhinitis. There was no correlation between severity of asthma and severity of AR and in most cases asthma precedes or started with AR.

\section{REFERENCES}

1. Grossman J. One airway, one disease. Chest. 1997;111(2):11-6. DOI: https://doi.org/10.1378/chest. 111.2_Supplement.11S

2. Bousquet J, Van Cauwenberge P, Khaltaev N. Allergic rhinitis and its impact on asthma. J Allergy Clin Immunol. 2001;108:147-334. DOI: https://doi.org/10.1067/mai.2001.118891

3. Simons FE. Allergic rhinobronchitis: The asthma-allergic rhinitis link. J Allergy Clin Immunol. 1999;104:534-40. DOI: https://doi.org/10.1016/S0091-6749(99)70320-9

4. Bousquet J, Vignola AM, Demoly P. Links between rhinitis and asthma. Allergy. 2003;58:691-706. DOI: https:// doi.org/10.1034/j.1398-9995.2003.00105.x

5. Casale TB, Amin BV. Allergic rhinitis/asthma interrelationships. Clin Rev Allergy Immunol. 2001;21:27-49. DOI: https://doi.org/10.1385/CRIAI:21:1:27

6. Togias A. Unique mechanistic features of allergic rhinitis. J Allergy Clin Immunol. 2000;105:559-604. DOI: https:// doi.org/10.1067/mai.2000.106885

7. Vonmutius E. The rising trends in asthma and allergic disease. Clin Exp Allergy. 1998;28(5):45-9. DOI: https:// doi.org/10.1046/j.1365-2222.1998.028s5045.x

8. Nathan RA, Meltzer EO, Selner JC, Storms W. Prevalence of allergic rhinitis in the United States. J Allergy Clin Immunol. 1997;99:808-14. DOI: https://doi.org/10.1016/S0091-6749(97)80040-1 
9. Leynaert B, Neukirch F, Demoly P, Bousquet J. Epidemiologic evidence for asthma and rhinitis comorbidity. J Allergy Clin Immunol. 2000;106:201-5. DOI: https://doi.org/10.1067/mai.2000.110151

10. Simons FE. Allergic rhinobronchitis: The asthma-allergic rhinitis link. J Allergy Clin Immunol. 1999;104:534-40. DOI: https://doi.org/10.1016/S0091-6749(99)70320-9

11. Passalacqua G, Ciprandi G, Canonica GW. The nose-lung interaction in allergic rhinitis and asthma: united airways disease. Curr Opin Allergy Clin Immunol. 2001;1(1):7-13. DOI: 10.1097/01.all.0000010978.62527.4e

12. Sibbald B, Rink E. Epidemiology of seasonal and perennial rhinitis: Clinical presentation and medical history. Thorax. 1991;46:895-901. DOI: https://doi.org/10.1136/thx.46.12.895 13.

13. Pal R, Dahal S, Pal S. Prevalence of Bronchial Asthma in Indian Children. Indian J Community Med. 2009;34(4): 310-6. DOI: https://doi.org/10.4103/0970-0218.58389

14. Sanjana JM, Mahesh PA, Jayaraj BS, Lokesh KS. Changing trends in the prevalence of asthma and allergic rhinitis in children in Mysore, South India. Eur Respir J. 2014;44(58):1187. DOI: https://erj.ersjournals.com/content/44/ Suppl_58/P1187

15. Becker AB, Abrams EM. Asthma guidelines: the Global Initiative for Asthma in relation to national guidelines. Curr Opin Allergy CL. 2017;17(2):99-103. DOI: https://doi.org/10.1097/ACI.0000000000000346

16. Bousquet J, Khaltaev N, Cruz AA, Denburg J, Fokkens WJ, Togias A, et al. Allergic Rhinitis and its Impact on Asthma (ARIA) 2008 update. Allergy. 2008;63:8-160. DOI: https://doi.org/10.1111/j.1398-9995.2007.01620.x

17. Bateman E, Hurd SS, Barnes PJ, Bousquet J, Drazen JM, FitzGerald M, et al. Global strategy for asthma management and prevention: GINA executive summary. Eur Respir J. 2008;31(1):143-78. DOI: https://doi.org/ $10.1183 / 09031936.00138707$

18. Bousquet J, Vignola AM, Demoly P. Links between rhinitis and asthma. Allergy. 2003;58:691-706. DOI: https:// doi.org/10.1034/j.1398-9995.2003.00105.x

19. Annesi-Maesano I. Epidemiological evidence of the occurrence of rhinitis and sinusitis in asthmatics. Allergy. 1999;54(57):7-13. DOI: https://doi.org/10.1111/j.1398-9995.1999.tb04401.x

20. Marogna M, Faligiani P, Bruno M, Massolo A, Riva G. The allergic march in pollinosis: Natural history and therapeutic implications. Int Arch Allergy Immunol. 2004;135:336-42. DOI: https://doi.org/10.1159/000082329

21. Pereira C, Valero A, Loureiro C, Davila I, Martinez-Cocera C, Murio C, et al. Iberian study of aeroallergens sensitisation in allergic rhinitis. Eur Ann Allergy Clin Immunol. 2006;38(6):186. PMID: 16929745

22. Bugiani M, Carosso A, Migliore E, Piccioni P, Corsico A, Olivieri M, et al. Allergic rhinitis and asthma comorbidity in a survey of young adults in Italy. Allergy. 2005;60:165-70. DOI: https://doi.org/10.1111/j. 1398-9995.2005.00659.x

23. Cirillo I, Vizzaccaro A, Tosca MA, Milanese M, Ciprandi G. Prevalence and treatment of allergic rhinitis in Italian conscripts. Eur Ann Allergy Clin Immunol. 2003;35(6):204-7.

24. Annesi-Maesano I, Beyer A, Marmouz F, Mathelier-FusadeP, Vervloet D, Bauchau V. Concurrent allergic diseases: a cross-sectional study in a French population. Allergy. 2006;61:390-1. DOI: https://doi.org/10.1111/j. 1398-9995.2006.01019.x

25. Kapsali T, Horowitz E, Diemer F, Togias A. Rhinitis is ubiquitous in allergic asthmatics. J Allergy Clin Immunol. 1997;99:138. DOI: https://doi.org/10.1016/S0091-6749(99)70320-9

26. Matsuno O, Miyazaki E, Takenaka R, Ando M, Ito T, Sawabe T, et al. Links between bronchial asthma and allergic rhinitis in the Oita Prefecture. J Asthma. 2006;43:165-7. DOI:https://doi.org/10.1080/0277090050049905327.

27. Bantz SK, Zhu Z, Zheng T. The Atopic March: Progression from atopic dermatitis to allergic rhinitis and asthma. J Clin Cell Immunol. 2014;5(2):202. DOI: https://doi.org/10.4172/2155-9899.1000202

28. Greisner WA, Settipane RJ, Settipane GA. Co-existence of asthma and allergic rhinitis: A 23-year follow-up study of college students. Allergy Asthma Proc. 1998;19:185-8. DOI: https://doi.org/10.2500/108854198778557836

29. Navarro. Coexistence of Asthma and Allergic Rhinitis in Adult Patients Attending Allergy Clinics: ONEAIR Study, J Investing Allergol Clin Immunology. 2008;13:18(4): 233-8. PMID 18714529 